\title{
Peran Wanita Tani Dalam Mendukung Pengembangan Desa Wisata Di Desa Kopeng Kecamatan Getasan Kabupaten Semarang
}

\section{(Role Of Women Farmers In Supporting Development Of Tourist Village In Kopeng, Getasan, Semarang District)}

\author{
Sutopo *) dan Astrid Ekaningdyah **) \\ *)Sekolah Tinggi IImu Pertanian Farming Semarang \\ **) Institut Sains dan Teknologi Pradita Tangerang Selatan \\ *Email : sutoposukadi@gmail.com
}

\begin{abstract}
ABSTRAK
Penelitian ini dilaksanakan di Desa Kopeng Kecamatan Getasan Kabupaten Semarang pada bulan Juli sampai Agustus 2019 bertujuan untuk mendeskripsikan usaha tanaman hias wanita tani sebagai pendukung pengembangan pariwisata, akses dan control wanita tani dalam usaha tanaman hias dan sumbangan pendapatan wanita tani dalam keluarga. Penelitian ini menggunakan metode survey. Dua belas wanita tani tanaman hias terpilih sebagai sampel dengan teknik purposive sampling. Data primer diperoleh dengan cara wawancara mendalam dan observasi. Data yang diperoleh dianalisis dengan teknik analisis deskriptif kualitatif. Hasil penelitian menunjukan bahwa tanaman hias yang dikembangkan dan diusahakan wanita tani di desa Kopeng dapat meningkatkan daya tarik wisatawan, akses dan control wanita tani dalam usaha tanaman hias tinggi dan sumbangan pendapatan wanita tani dalam keluarga rata-rata sebesar Rp 2.245.000,- perbulan
\end{abstract}

Kata Kunci : wanita tani, tanaman hias, pariwisata

\section{ABSTRACT}

Research conducted in Kopeng Village, Getasan Sub-District, Semarang Regency July to August 2019. This study aims to describe the efforts of farm women in ornamental plants as supporting the development of tourism, access and control of farm women in the ornamental plant business and contribution to the increase family income. This research used survey method. Twelve ornamental plant women were selected as samples by using purposive sampling technique. Primary data obtained by in-depth interviews and observations. Data analysis method at this research is descriptive analysis by using qualitative approachment. The results showed that in the ornamental plants who developed and cultivated by women farmers in Kopeng village could increase the attractiveness of tourists, access and control of farm women in the business is high and the earnings contribution to family income an average of $R p 2,245,000$ permonth.

Keywords: farm woman, ornamental plants, tourism

\section{PENDAHULUAN}

Usahatani merupakan salah satu usaha yang yang berpotensi untuk menunjang kehidupan keluarga di pedesaan. Peran serta wanita merupakan suatu proses menuju kemandirian sehingga wanita dapat terlepas dari ketergantungan. Motivasi wanita ingin bekerja menurut Ridayati (2014), adalah untuk menambah penghasilan keluarga, tidak tergantung pada suami mengisi waktu luang dan mengembangkan diri. Tenaga kerja wanita merupakan sumber daya insani yang memiliki peran sebagai pencari nafkah tambahan bagi keluarganya (Astrid , 2014). Menurut Fauzia.A et al, 2007, curahan waktu kerja wanita untuk usaha tani sayuran 131,43 jam/musim tanam dan sumbangan pendapatan untuk keluarga sebesar Rp 312.643.

Desa Kopeng Kecamatan Getasan Kabupaten Semarang merupakan salah satu daerah destinasi 
wisata di Jawa Tengah yang mempunyai ragam sumberdaya alam berlimpah kekayaan alam merupakan modal utama dalam meningkatkan taraf hidup manusia melalui pemanfaatan sumberdaya alam yang dimiliki. Desa Kopeng terkenal dengan produk tanaman hortikultura seperti sayuran, dan buah-buahan sehingga desa Kopeng menjadi daya tarik tersendiri bagi wisatawan. Dewasa ini banyak dikembangkan usaha tanaman hias yang saat ini mempunyai prospek yang menjanjikan. Menurut Bambang (2006) pengembangan suatu obyek wisata harus dapat menciptakan produk stily yang baik yaitu daya tarik dan kekhususan /berbeda dengan daerah wisata yang lain. Pengembangan usaha tanaman hias di desa Kopeng didominasi oleh para wanita tani (istri petani horti) saat ini usaha tanaman hias semakin berkembang dan ini dapat terlihat banyaknya usaha tanman hias disepanjang jalan desa Kopeng maupun didusun-dusun sekitar obyek wisata.

Berangkat dari latar belakang diatas perlu dilakukan kajian tentang peran wanita tani tanaman hias dalam upaya pengembangan desa wisata, kajian ini bertujuan untuk mendeskripsikan usaha tanaman hias wanita tani dapat sebagai pendukung pengembangan pariwisata, akses dan kontrol wanita tani dalam usaha tanaman hias dan sumbangan pendapatan wanita tani dalam keluarga.

\section{METODE PENELITIAN}

Penelitian ini dilakukan ini di Desa Kopeng Kecamatan Getasan Kabupaten Semarang Penelitian ini menggunakan metode survey dengan penentuan sampel menggunakan teknik purposive sampling (berdasarkan syarat tertentu): yaitu responden adalah istri petani horti setempat dan aktif melakukan kegiatan usaha tanaman hias sehingga diperoleh responden sebanyak 12 wanita tani. Data primer diperoleh dengan cara wawancara mendalam dan observasi partisipasi untuk mendapatkan informasi tentang tanaman hias yang diusahakan wanita tani sebagai pendukung pengembangan pariwisata, akses dan kontrol wanita dalam usaha tanaman hias dan sumbangan pendapatan wanita tani dalam keluarga. Data sekunder diperoleh dari instansi terkait meliputi keadaan penduduk, topografi dan data penunjang yang lain. Data yang diperoleh dianalisis secara deskriptif kualitatif (yaitu analisis kualitatif lebih kepada faktor-faktor atau fakta yang terdapat di lapangan sesuai dengan latar alamiahnya (Moliong, 2007) disajikan dalam bentuk naratif.

Analisis pendapatan perempuan menggunakan analisis kuantitatif dengan rumus:

$$
\begin{aligned}
& P d=T R-T C \\
& P d=\text { pendapatan usaha } \\
& T R=\text { total penerimaan dan } \\
& T C=\text { total biaya }
\end{aligned}
$$

\section{HASIL DAN PEMBAHASAN \\ Keadaan Umum daerah Penelitian}

Desa Kopeng adalah salah satu Desa di wilayah Kecamatan Getasan Kabupaten Semarang dengan luas wilayah $800 \mathrm{Ha}$. Desa Kopeng terdiri 9 Dusun, yaitu Dusun Plalar, Sidomuukti, Sleker, Kopeng, Dukuh, Payeman, Cuntel, Blancir dan Kasiran. Desa Kopeng berada di ketinggian tempat 1.450-1.500 meter dari permukaan laut (dpl).

Adapun batas-batas wilayah dari Desa Kopeng sebagai berikut: Utara: Desa Wates, Kecamatan Getasan, Selatan: Desa Jrakah, Kecamatan Selo, Barat: Desa Magelang, Kecamatan Ngablak, Timur: Desa Batur, Kecamatan Getasan. Kondisi geografis Desa Kopeng merupakan tanah merah yang terbagi menjadi beberapa lahan pekarangan/bangunan seluas $68 \mathrm{ha}$, tegal/kebun, tanah sawah seluas $424 \mathrm{Ha}$, tanah hutan lindung seluas $188 \mathrm{Ha}$. Mata pencaharian penduduk sebagian besar sebagai petani hortikultura sebanyak 
2760 jiwa, lain - lain 44 jiwa

\section{Identitas responden}

Umur responden berkisar antara usia 35 sampai 55 tahun, kisaran usia tersebut masih termasuk usia produktif sehingga mampu mencurahkan tenaga kerja secara optimal pada usaha yang dijalankan. Mata pencaharian pokok suami responden $100 \%$ pada sektor pertanian, pendidikan responden sebagian besar $(80,00 \%)$ adalah sekolah dasar dan yang sederajat, sedangkan $20,00 \%$ sisanya adalah berpendidikan SMP atau yang sederajat.

Wanita tani usaha Tanaman Hias Sebagai Pengembangan Pariwisata

Desa Kopeng sejak dahulu dikenal sebagai penghasil tanaman hortikultura terutama terkenal sebagai penghasil sayuran dan buah-buahan, selain itu desa Kopeng yang terletak di lereng Merbabu dikenal dengan keindahan alamnya sehingga mempunyai daya tarik sendiri bagi para wisatawan lokal maupun manca Negara. Dewasa ini dengan berkembangnya dunia wisata di Indonesia memperluas dan memeratakan kesempatan berusaha, lapangan pekerjaan dan tentu saja mendorong perkembangan suatu daerah.

Desa Kopeng yang merupakan salah satu daerah destinasi wisata sejak beberapa tahun belakangan ini wanita tani mulai mengembangkan tanaman hias sebagai salah satu produk unggulan untuk lebih menarik minat para wisatawan selain produk yang sudah populair yakni sayur- mayur dan buahbuahan. Berdasarkan hasil observasi dan wawancara mendalam yang dilakukan ada beberapa factor yang mendorong wanita tani mengembangkan usaha tanaman hias, dapat dideskripsikan sebagai berikut:

1. Faktor internal yaitu untuk mengisi waktu I u n w wita, memanfaatkan lahan pekarangan hal ini sesuai pendapat Ashari, et al 2012, bahwa keterbatasan lahan pertanian dapat diatasi melalui pemanfaatan lahan pekarangan, menambah penghasilan keluarga, bekerja tidak harus meninggalkan rumah, usaha tanamn hias tidak memerlukan tenaga fisik yang berat

2. Faktor eksternal yaitu kemudahan mendapatkan bahan baku, lokasi tempat tinggal yang strategis, akses dari obyek wisata dekat dan terjangkau ( mudah), harga jual tanaman hias lebih menjajanjikan adanya dukungan instansi terkait dan kelompok tani horti untuk mengembangkan tanaman hias.

\section{Pengembangan Usaha Tanaman Hias Wanita Tani di Desa Wisata Kopeng}

Strategi pengembangan adalah perpaduan dan pengintegrasian antara factor-faktor internal dan eksternal untuk mencapai tujuan, sasaran dan kinerja dengan memberdayakan sumberdaya alam secara efektif dan efisien. Strategi pengembangan tanaman hias disusun berdasarkan hasil analisis swot. Berdasarkan hasil penelitian didapatkan faktor-faktor internal dan eksternal yang dapat dideskripsikani sebagai berikut:

1. Kekuatan (Strengths) berdasarkan faktor internal :

a. Banyak ragam jenis tanaman hias lokal yang tersedia dan menarik

b. Iklim dan kondisi tanah mendukung untuk tanaman hias

c. Media tanam dan pupuk organik banyak tersedia

d. Semakin lama tanaman hias dipelihara semakin meningkat nilai jualnya

2. Kelemahan (Weakness) berdasarkan faktor internal :

a. Beberapa jenis tanaman hias lokal tidak cocok untuk daerah dataran 
rendah

3. Peluang (Opportunity) berdasarkan faktor eksternal :

a. Tanaman hias desa Kopeng banyak diminati wisatawan

b. Tanaman hias mudah perawatan dan resiko usaha lebih kecil

c. Lokasi usaha strategis

d. Lingkungan mendukung

4. Ancaman (Threath) berdasarkan faktor eksternal:

a. Persaingan usaha tanaman hias

\section{Analisis faktor Internal dan faktor Eksternal}

I. Faktor internal disusun berdasarkan kekuatan dan kelemahan yang dianggap penting dan hasil penelitian dapat dideskripsikan sebagai berikut:

1. Jenis tanaman hias lokal banyak tersedia. Desa Kopeng merupakan daerah dataran tinggi yang terletak dilereng gunung Merbabu banyak sekali mempunyai sumber daya alam yang berlimpah salahsatunya adalah tanaman hias, jenis tanman yang tersedia antara lain seperti: Bunga Pitunia, kaktus, aglaonema, tapak doro, puring, begonia bermacam jenus anggrek dan lain sebagainya. ("Jenis tanaman hias asli desa Kopeng banyak jenisnya pak dan sudah lama dibudidayakan oleh petanidisini ")

2. Iklim dan kondisi tanah mendukung untuk tanaman hias. Desa Kopeng ada pada ketinggian $1450 \mathrm{~s} / \mathrm{d} 1500 \mathrm{~m}$ dpl memiliki kondisi tanah yang subur dan suhu yang sejuk sehingga cocok untuk budidaya tanaman pangan/hortikultura maupun tanaman hias baik lokal maupun dari daerah lain ("Kalau di Kopeng Sayur mayur, buah-buahan maupun tanaman hias dapat tumbuh dan berkembang dengan baik")

3. Media tanam dan pupuk organik banyak tersedia. Desa Kopeng merupakan salah satu daerah penghasil tanaman pangan juga sebagai penghasil susu sapi segar dan daging ,masyarakat di Kopeng selain bertani juga mempunyai ragam usaha ternak seperti Sapi perah, sapi potong, ternak babi dan ayam baik petelur maupun pedaging. Dari kotoran ternak yang melimpah dimanfaatkan petani sebagai pupuk organic dan membat media tanam.("Pak kalau di Kopeng pupuk organik dan media tanam banyak tersedia bahkan kami dapat membuat sendiri dari kotoran ternak kalaupun membeli murah harganya ")

4. Semakin lama tanaman hias dipelihara semakin meningkat nilai jualnya. Tanaman hias yang dibeli dari baik lokal maupun luar daerah seperti anggrek, monstera, parijoto semakin dipelihara/dirawat harga jualnya semakin tinggi (menurut bu Sumiyati " contohnya pak kalau saya kulakan monstera , dengan harga $R p$ 125.000,- kondisi masih kecil daun belum lebar daunnya saya pelihara kurang lebih 2 bulan harga jualnya bisa mencapai $R p$ 400.000,-tapi kalau langsung laku harganya hanya Rp 150.000,-")

5. Beberapa jenis tanaman hias lokal tidak cocok untuk daerah dataran rendah. Beberapa tanaman hias lokal yang ditawarkan tidak cocok untuk dipelihara didaerah dataran rendah sedangkan banyak wisatawan lokal berasal dari daerah dataran rendah seperti Kota Semarang ,sehingga tidak dapat ditawarkan dengan harga yang tinggi . (", tanaman asli Kopeng seperti petunia dan begonia hanya baik hasilnya bila 
ditanam di dataran tinggi tapi tidak tahan lama di dataran rendah padahal Pak, banyak wisatawan yang datang dari kota Semarang sehingga nilai jualnya rendah maksimal rata-rata hanya $R p$ 10.000 ,-pertanaman ")

\section{Faktor Eksternal}

Faktor eksternal disusun berdasarkan peluang dan ancaman dideskripsikaan sebagai berikut :

1. Tanaman hias desa Kopeng banyak diminati wisatawan. Ragam tanaman hias yang tersedia dengan berbagai ragam bunga hias seperti tapak doro, Bunga mawar, anggrek bulan, berbagai jenis anggrek tanah, begonia dan lain-lain yang ditawarkan selalu terjual dengan cepat terutama yang dapat dipelihara didataran rendah maupun dataran tinggi (" Sekarang dengan adanya usaha pengembangan tanaman hias setiap hari ada kunjungan konsumen dari luar daerah maupun daerah sekitar membeli tanaman pak, kalau hari biasa yang datang membeli rata-rata 3 orang sedangkan pada hari libur bisa mencapai rata-rata 10 orang, rata-rata wisatawan tertarik dengan tanaman hias yang ditawarkan ditunjukkan dengan harga yang ditawarkan tidak pernah ada penawaran.")

2. Tanaman hias mudah perawatan dan resiko usaha lebih kecil. Tanaman hias yang berasal dari daerah setempat maka perawatan mudah dan bahkan tumbuh dengan sendirinya karena dukungan faktor alam dengan suhu yang sejuk dan tanah yang subur, sehingga resiko tanaman mati kecil dan hama dapat diatasi tidak ada batasan waktu semakin lama tidak terjual harga justru makin meningkat ("Pak kalau tanaman has itu $90 \%$ hampir tidak ada yang rusak/mati bahkan semakin lama dirawat harga menjadi lebih mahal ")

3. Lokasi usaha strategis. Daerah Kopeng merupakan daerah wisata dan dekat dengan obyek wisata terletak di jalan raya Salatiga Magelang sehingga merupakan jalur padat dekat dengan pasar sayur-mayur dan buah-buahan yang disediakan daerah setempat untuk destiinasi wisata, lokasi lebih mudah ditemukan karena berada dipinggir jalan raya mmenjadi tidak pernah sepi pengunjung dan bagi wanita tani usaha tanaman hias dapat menekan efisiensi biaya dan mengurangi ancaman. ("Rata-rata disini kami wanita tani membuka kios tanaman hias dihalaman rumah depan, samping maupun belakang rumah yang menghadap jalan raya")

4. Lingkungan mendukung . Lingkungan di desa Kopeng mendukung untuk usaha tanaman hias karena banyak dari masyarakat yang mata pencaharian selain tanaman hortikultura disela-sela tanaman hortikultura selalu ditanami tanaman hias karena dianggap lebih menguntungkan dibanding tanaman sayur dan keadaan tanah serta iklim sangat mendukung untuk tumbuh dan berkembangnya tanaman

5. Persaingan usaha tanaman hias. Pesaing usaha tanaman hias oleh para wanita tani didesa Kopeng dapat berupa para penjual/ pedagang tanaman hias dari luar daerah Kopeng yaitu dengan membuka kios di obyek-obyek wisata yang ada di daerah 
Kopeng, selain itu desa Kopeng berdekatan dengan tempat wisata lain seperti Bandungan , Sumowono dan Ambarawa dan perbatasan dengan kota Magelang ("Wah sekarang orang berusaha tanaman hias tidak hanya para wanita tani disini tapi juga luar daerah yang menawarkan tanaman hiasnya di Obyek wisata atau pasar")

Dikembangkannya tanaman hias oleh para wanita/isteri petani hortikultura sekarang ini menjadi daya tarik tersendiri bagi wisatawan dating ke desa Kopeng. Hal ini ditunjukkan dari kunjungan wisatawan tidak hanya dihari libur dan akhir pekan tetapi sekarang setiap hari ada pengunjung/konsumen yang datang ("Kalau dulu sebelum tanaman hias berkembang seperti sekarang pak, pengunjung hanya ramai dihari libur saja sekarang setiap hari pasti ada konsumen/wisatawan yang dating untuk membeli tanaman hias")

Berdasarkan analisis SWOT dapat dideskripsikan bahwa usaha tanaman hias di desa Kopeng memiliki peluang dan kekuatan yang lebih besar untuk menjadi daya dukung dalam menarik wisatawan walaupun masih ada kelemahan yang masih perlu diperbaiki antara lain perbaikan mutu dan varietas tanaman hias lokal sehingga dapat menjadi ciri khas atau ikon desa wisata Kopeng sekaligus meningkatkan daya saing dengan destinasi wisata yang lain

\section{Akses dan Kontrol Wanita Tani dalam Usaha Tanaman Hias}

Wanita tani di desa Kopeng Kecamatan Getasan mempunyai akses dan kontrol yang tinggi dalam usaha tanaman hias. Hal ini dapat diwujutkan dari kegiatan usaha tanaman hias baik dalam penentuan waktu kegiatan, dalam melakukan pemeliharaan/perawatan tanaman seperti mengganti media tanam, pemupukan, memilih dan menentukan jenis tanaman yang ditawarkan, menentukan harga tanaman hias dan kegiatan lainnya didominasi oleh wanita tani. Dalam hal pendidikan/penyuluhan tentang tanaman hias baik melalui Dinas terkait maupun lembaga yang kompeten (kelompok tani, media informasi pertanian dan lain-lain), para wanita tani ini selalu mengikuti secara aktif. Usaha tanaman hias di desa Kopeng merupakan tanggung jawab bersama antara suami dan isteri sehingga pengambilan keputusan dalam hal modal diputuskan secara bersama. Pendapatan yang diperoleh dari usaha tanaman hias pemanfaatan penggunaannya diatur dan ditentukan oleh wanita.

\section{Sumbangan Pendapatan Wanita Tani Tanaman Hias dalam Keluarga}

Usaha tanaman hias di desa Kopeng dilakukan oleh sebagian wanita/isteri. Awalnya hanya beberapa wanita yang mengembangkan usaha tanaman hias, sebagian besar mereka melakukan usaha pembibitan sayuran dan membantu suami bertani di ladang saat ini usaha tanaman hias berkembang pesat sebagian besar wanita yang mengusahakan pembibitan sayuran beralih ke usaha tanaman hias ( " Tanaman hias itu pak pendapatannya lebih besar dibanding usaha pembibitan sayuran yang saat Ini sudah mulai banyak saingan, selain itu usaha tanaman hias resiko lebih kecil dan tidak memerlukan tenaga phisik yang besar dibanding usaha pembibitan tanaman sayuran")

Tempat usaha tanaman hias ratarata menggunakan lahan pekarangan tempat tinggal ( didepan rumah, disamping atau dibelakang rumah). Banyak jenis tanaman hias yang diusahakan didesa Kopeng baik tanaman lokal maupun dari daerah lain seperti dari Cilacap ,Magelang dan Bandung. Tempat usaha dibuatkan dalam bentuk kios terbuka rata-ratabangunan semi 
permanen dengan biaya pembuatan ratarataRp 5.000.000,- dengan daya tahan selama $3 \mathrm{~s} / \mathrm{d} 5$ tahun tergantung dari kualitas bahan bangunan.

Harga beli tanaman hias rata-rata untuk tanaman lokal antara lain: Pitunia, kaktus berkisar Rp 5.000,- dalam satu bulan rata-rata terjual 150 buah tanaman dengan harga jual Rp 10.000,- jenis Aglonema, puring, begonia harga beli rata-rata $\mathrm{Rp} 10.000$,- minimal harga jual Rp 15.000,- satu bulan rata-rataterjual 30 buah tanaman, jenis anggrek harga beli Rp 50.000,- dengan harga jual rata-rata Rp 100.000,- dalam satu bulan rata-rata terjual 10 buah. Anggrek luar daerah pembelian $\operatorname{Rp} 75.000$,- dijual dengan harga rata-rata minimal $\mathrm{Rp} 125.000$,sebulan terjual 10 buah

Jenis Monstera harga beli ratarata $\mathrm{Rp} 300.000$,- minimal harga jual $\mathrm{Rp}$ 400.000,-rata-rataterjual 4 buah, jenis parijoto harga beli Rp 125.000,- harga jual rata-rataminimal $\mathrm{Rp} 200.000$,- rata rata perbulan terjual 10 buah.

Media tanam dan pupuk organik banyak tersedia di desa Kopeng karena selain matapencaharian petani, juga banyak sebagai peternak baik, ayam, sapi perah dan babi. Sehingga pengeluaran untuk pembelian pupuk dan media tanam rata-rata dalam satu bulan mengeluarkan biaya $\mathrm{Rp}$ 125.000,- untuk perawatan tanaman seperti penggantian media tanam, memupuk dan penyiraman serta pemindahan tanaman dilakukan sendiri oleh wanita tani dan keluarga.

Pemasaran tanaman hias selama ini rata-rata masih dilakukan secara langsung yakni didatangi konsumen ditempat usaha atau kerumah.

\section{Analisis Pendapatan Usaha Tanaman Hias Perbulan}

$\begin{array}{lc}\text { Pendapatan adalah total penerimaan dikurangi total biaya } & \text { ( TR }-\mathrm{TC} \text { ), } \\ \text { Biaya/bulan } & \\ \text { Pembelian tanaman hias local dan non local } & \mathrm{Rp} 4.750 .000,- \\ \text { Tanah dan pupuk organik } & \mathrm{Rp} 125.000,- \\ \text { Plastik(polybag) pot } & \mathrm{Rp} 180.000,- \\ \text { Tenaga kerja/perawatan tanaman } & \mathrm{Rp} 200.000,- \\ \text { Penyusutan kios dan alat } & \mathrm{Rp} 100.000,- \\ \text { Lain - lain } & \mathrm{Rp} 200.000,- \\ \text { total penerimaan } & \mathrm{Rp} 5.555 .000,-\end{array}$

Penerimaan

Penjualan tanaman lokal $150 @$ Rp 10.000,- = Rp 1.500.000,-

Aglaonema

Anggrek Lokal

$30 @ R p \quad 15,000,-=R p \quad 450.000,-$

Anggrek Non Lokal

$10 @ R p 100.000,-=\operatorname{Rp~1.000.000,-~}$

Monstera

$10 @ R p 125.000,-=\operatorname{Rp~1.250.000,-~}$

Parijoto

$4 @ \operatorname{Rp} 400.000,-=\operatorname{Rp} 1.600 .000,-$

Total penerimaan

$10 @ R p 200.000,-=R p 2.000,000,-$

Rp 7.800.000,-

Pendapatan bersih dalam satu bulan/periode produksi adalah

$$
=R p, 7.800 .000-R p 5.555 .000=R p 2.245 .000,-
$$




\section{KESIMPULAN}

Dari hasil penelitian yang telah dilaksanakan dapat disimpulkan bahwa:

1) Jenis tanaman hias yang dikembangkan/diusahakan wanita didesa Kopeng dapat meningkatkan daya tarik kunjungan wisatawan

2) Akses dan kontrol wanita dalam usaha tanaman hias tinggi baik pada pemilikan, pendidikan maupun modal

3) Sumbangan pendapatan wanita d a la m k luarga dari usahatanman hias rataratasebesar $\mathrm{Rp}$ 2.245.000,- per bulan

\section{DAFTAR PUSTAKA}

Ashari, Saptana dan Purwantini, TB, 2012. Potensi dan Proyek Pemanfaatan Lahan Pekarangan Untuk Mendukung Ketahanan Pangan. Forum Penelitian Agro Ekonomi 30 (1):13-30

Astuti, Asri Wahyu W, 2013. Peran ibu rumah Tangga Dalam Meningkatkan Kesejahteraan Keluarga di Desa Bejen Kecamatan Bejen Kabupaten Temanggung. Skripsi. Semmarang. Fakultas IImu pendidikan Universirtas Negeri Semarang.
Bambang Pamulardi, 2006 . Pengembangan Agrowisata berwawasan Lingkungan di Desa Wisata Tingkir.http : //Penelitian Pengembangan Agrowisata .com

Fauzia A, Nukmal H, Hamziah, 2007. Partisipasi Wanita Tani Dalam Usaha Tani Sayuran dan $\mathrm{Hubungannya}$ De ngan Pendapatan Keluarga di Kelurahan Sukarami Palembang. Journal Komunikasi dan Pengembangan Masyarakat. Vol.3 No.2 PP 122 -130

Moleong, 2007 Metodologi Penelitian Kualitatif PT. Remaja Rosdakarya Bandung

Rudayati, Dyah Suwarti, 2014. Peran dan Partisipasi Istri Buruh tani Dalam u p a a P e n ing k a t a n Kesejahteraan Keluarga. Journal ilmiah Teknik Industri Vol. 2.no. 2 $83-91$

Sukartawi, 2003. Teori Ekonomi Produksi dengan pokok bahasan analisa Cobb Douglass PT Raya grafindo, Jakarta. 